\title{
Procurement Performance Practices and WASTE MANAGEMENT IN TEXTILE MANUFACTURING FIRMS IN NAIROBI City COUNTY
}

\author{
Enock Gideon Musau \\ Lecturer School of Business and Economics, Department of Management Science \\ Kisii University, Kenya
}

\begin{abstract}
Waste management in Kenya's urban centers is becoming a momentous task considering the country's desire for a middle income industrial economy. The National Environment Management Authority (NEMA) is concerned with the growing rate of waste generation that does not match the rate of collection. Among the industrial sectors that are poised to play a significant role in realization of the middle income industrial status is the textile sector. However, this is a sector that contributes to high volumes of waste generation in Kenya. Yet, it is envisaged that adoption of waste-sensitive procurement could be the panacea to waste management in the sector. The purpose of this study was therefore to investigate the effect of procurement performance practices on waste management in textile firms in Nairobi City County. This study was grounded on the positivist research paradigm in adopting the ex-post facto research design, to interrogate the direct effects of the three procurement practices on waste management. Cochran's sample size formula was used to decide on a sample size of 142 employees. Stratified and simple random sampling techniques were used to draw the required sample of employees from the respective textile firms. Data were collected using a structured questionnaire comprising of four sections in line with the four constructs under study. Multiple regressions analyses were run to test the postulations made. The study confirmed that textile firms under investigation were not emphasizing more on waste prevention and minimization when procuring materials. This was deemed to be serious considering that supplierprequalification, invitation to tender, and contract structure were all found to be significant and positive predictors of waste management in the textile firm's context. The conclusions made from the study findings were that; textile firms in Nairobi City County were facing the challenge of waste management due to their laxity in emphasizing waste-sensitive procurement practices. The firms however stand to gain by leveraging upon supplier pre-qualification, invitation of bids, and contract structure that are centric to waste generation. The findings of this study contribute to the theory and practice of waste management by showing that, waste is best managed at the procurement stage. This therefore implies that textile and waste management stakeholders have the onus of coming up with waste management parameters which, supplier pre-qualification, invitation to tender, and contract structure processes should aim at. Future studies should take into account other procurement practices that can be engaged to prevent and minimize waste. Moreover, there may be need to expand the geographical scope of the firms in order to boost external validity
\end{abstract}

\section{KEYWORDS}

Waste management, supplier pre-qualification, invitation to tender, contract structure, procurement performance 


\section{INTRODUCTION}

Waste generation and management particularly in urban centers is becoming a major concern. Kenya is targeting a middle income industrial status by 2030 as outlined in its development blue print vision 2030. Consequently, most urban centres in Kenya are experiencing enhanced activities aimed at industrial development. With such increased pace of industrial developmentbased activities, it has been noted that there has been an increase in rural urban migration, and by extension growth in urban populations, and with it increased solid waste generation emanating from enhanced industrial and domestic activities (Gakungu et al., 2012).

The increase in waste generation has however not been met with an analogous growth in its management. According to the National Environment Management Authority (NEMA), as at 2014, Nairobi town generated an estimated waste amounting to 2400 tons/day of which $20 \%$ was uncollected; Nakuru generated 250 tons/day with $37 \%$ remaining uncollected; Thika generated 140 tons/day but $40 \%$ was uncollected; Mombasa generated 2200 tons/day per yet $35 \%$ remained uncollected; Eldoret generated 600 tons/day with $45 \%$ remaining uncollected, and Kisumu generated 400 tons/day of which only $20 \%$ was collected (NEMA, 2015).

NEMA observes that a variety of waste streams that includes; municipal, domestic, industrial and hazardous waste are generated in Kenya and that the composition of waste varies across industries, businesses and households (NEMA, 2015). NEMA argues that, management of these streams of waste is complicated by the fact that existing waste collection and disposal systems in most towns and cities are inefficient. Besides, transportation modes used to move waste are responsible for littering which makes waste an eyesore. Meanwhile, waste disposal is also a challenge considering that most counties are devoid of adequate and proper sites for waste disposal.

The textile industry ranks as a critical sector in the realization of Kenya's manufacturing sector's GDP contribution target of $20 \%$ by 2022 (GoK, 2017). Under this target, the textile industry is expected to make a contribution of $\$ 2 \mathrm{bn}$. Despite the important role which the industry is expected to play, it is identified as one of the industries which contribute majorly to waste generation in Kenya (Kinyanjui, Mburu \& Waithaka, 2013). Other than post-consumer wastes such as 'Mitumba' brought into the Kenyan market, and which due to their short lifespan require constant disposal, the industry also generates numerous pre-consumer wastes.

It is for instance postulated that textile productions potentially contribute an equivalent of $16.9 \mathrm{~kg}$ $\mathrm{CO} 2$ per $\mathrm{kg}$ of $50 \%$ cotton and $50 \%$ polyester; and an equivalent of $25 \mathrm{~kg} \mathrm{CO} 2$ per $\mathrm{kg}$ of textiles (Sundqvist \& Palm, 2010). Moreover, it is acknowledged that leather and textile production degrades water and soils owing to effluent toxic arising out of processes such as dyeing (Kinyanjui et al., 2013). Textiles have also been associated with problems in landfill considering that synthetic fibers do not decompose; and although woolen garments are capable of decomposing, they in the process produce methane hence contributing to global warming (Kinyanjui et al., 2013).

In an endeavour to manage the spiraling waste and associated risks, Kenya has put in place a number of policies and legal provisions, including the National Solid Waste Management Strategy of 2015 (NEMA, 2015). However, the role that procurement performance plays towards waste management in the textile industry has not been explored. It is acknowledged that organizations are able to influence the amount of waste produced during purchasing and procurement (UNDP, 2008). It is postulated therefore that significant reductions in waste are able to be realized by focusing on the purchasing decision process (Sustainability Exchange, 2020). 
Procurement processes such as pre-qualification, invitation to tender and contract structure are critical in procurement performance, and may be relied upon to manage waste. Through prequalification for instance, potential contract bidders can be screened for waste sensitivity (Asian Development Bank (ADB), 2018). Also by inviting tenders, competition is encouraged through which suppliers capable of delivering objectives towards waste management are identified (Bid Detail, 2018). In the event of such potential waste management benefits that may accrue from prudent use of procurement processes, this paper seeks to contribute to existing waste management scholarship by analyzing the direct effects of procurement performance on waste management in the textile supply chain context.

\section{Literature REVIEW AND HYPOTHESES FORMULATION}

This study was anchored on the theory of waste management which postulates that managing waste, amounts to an endeavour to prevent harm to the environment and human health. Choice of this theory for this study was informed by the understanding that although the textile industry plays a critical role in Kenya's economic development agenda, it remains a source of waste generation, which does require being managed.

\subsection{Waste and Waste Management}

The concept of waste is perceived divergently among organizations and scholars. The Organization of Economic Cooperation and Development (OECD, 2003) for instance, defined waste as those materials, with the exception of radioactive materials, which are intended for disposal. The United Nation's Environment Programme (UNEP, 2004) on the contrary defined waste as substances which are due for disposal on the basis of national laws. Waste has also been viewed as non prime materials which have become obsolete to the generators interests and are due for disposal (UN Statistics Division, 2011). According to Michael-Agwuoke (2012), waste relates to residual materials arising from human activities, and which have no chance to be reused as a resource, or to be recycled into the material production process. From the Kenyan context, Prof. Geoffrey Wahungu, the director general of NEMA perceives waste as a resource which has the potential to create wealth, employment and reduce pollution of the environment if well managed (NEMA, 2015).

Waste management is therefore perceived as an act of collecting, treating and disposing materials that are no longer useful in production processes (Nathanson, 2020). Nathanson argues that poor management of waste poses a threat to health and the environment by way of, outbreaks of vector-borne diseases caused by an increase in rodents and insects. Generation of waste has been associated with most human activities (Brunner \& Rechberger) and although it remains prehistoric (Chandler et al., 1997) it has increased in both the volume and variety in contemporary society (Amasuomo \& Baird, 2016).

\subsection{Waste Management in the Textile Industry}

The textile manufacturing supply chain is involved in numerous activities which result into waste generation (Ashfaq \& Khatoon, 2014). Ashfaq and Khatoon recognize the fact that activities such as washing / drying, weaving, warp preparation, dyeing, finishing, printing, process and quality control, and warehousing are among the range of activities undertaken by textile manufacturers. These activities result in generation of soft and hard fibre wastes, off-cuts, beaming wastes, and packaging (Ashfaq \& Khatoon, 2014). Moreover, waste water ranks as the largest waste by volume in the textile sector owing to the fact that 200 litres of water is required for each kilogram of fibre in wet finishing processes (Sachidhanandham, 2018). 
A number of waste management strategies and technologies have been advanced for managing waste in the textile industry context. Reusing is a strategy which involves putting the product into use again to serve the same purpose and may require re-distribution and resale (Fletcher, 2008); recycling on the other hand involves shredding or pulling materials into small fibres which, are then mixed with non-used fibres to produce new fabrics; and in some cases to produce other products like panels for sound insulation, carpets or industrial filling (DEFRA, 2009). The third potential strategy known as refashioning involves the interception of reclaims, clothing, re-cuts and refashioning to create new loops by returning them into the clothing stream (Fraser, 2009). In Kenya, NEMA advocates for an integrated approach which guarantees protection and conservation of the environment (NEMA, 2015). Consequently, strategies such as waste prevention and minimization are given utmost priority. Procurement functions that would maximize waste prevention and minimization could therefore be considered of primal importance.

\subsection{Procurement prequalification and waste management}

Pre-qualification as a concept is defined as a process which is used to vet and ascertain a supplier's financial stability, firm resources, current workload, technical capacity, past performance and reputation among other contract qualification requirements (Chao \& Hsiao, 2013). In the Kenyan context, the procurement function has notably been riddled with corrupt practices and cost escalation (Ntayi, 2013). Pre-qualification in public institutions is therefore perceived as a strategy to try and provide a level playing ground by fostering competition in processes of services and goods contracting, acquisition, and disposal.

Several scholars have and continue to demonstrate the positive impact of supplier prequalification or evaluation as it is often referred to, on firm performance in diverse contexts. An evaluation of suppliers capability through pre-qualification has for instance been found to be beneficial in the auto mobile sectors in China (Nagao, 2012) and Thailand (Jens, 2014); in the textile /apparel sector in South Africa where it plays a role in profitability (Pikonsova \& Prusa, 2013); in manufacturing firms in Kenya where it significantly influences performance (Naibor \& Moronge, 2018); and in procurement performance in the judiciary context in Kenya (Limo, Iravo \& Lagat, 2017) among others.

It is apparent that existing studies on the impact of supplier pre-qualification mainly do so in the contexts of procurement performance and firm performance. However, no explicit evidence exists on the consequence of supplier pre-qualification or evaluation on waste management in the textile supply chain. The question then is whether supplier pre-qualification can be leveraged upon to prevent or minimize textile waste. Hypothesis one therefore postulated that

H01: Supplier pre-qualification has no significant influence on waste management in the textile industry in Kenya.

\subsection{Invitation to tender and waste management}

An invitation to tender (ITT) commonly known as call for bids or request for tenders, relates to a formal and legal process of seeking tender offers with a view to selecting the most appropriate supplier or service provider (Tasmania, 2006). According to sustainable Urban Economic Development Programme (SUED), the ITT lays out details of the tender process to bidders, and ensures equal consideration to all tenders (SUED, 2019). Through tendering, potential suppliers outline their offer on the pricing and time limits within which they commit to supply the specified goods, services and work (Lysons \& Farrington, 2006). Tendering therefore aims at 
competitiveness; transparency, fairness and accessibility, and probity which are needed to eliminate nepotism and offer value for money (World Bank, 2008).

Evidence in existing literature, demonstrates that inviting suppliers to tender has brought transparency and reduced corruption in Nakuru County Government leading to enhanced performance (Waruguru, 2015). Moreover, it has been shown that procedural and relational capability tendering significantly and positively affects contract win-ratio and percentage of total revenue in the SME context (Flynn \& Davis, 2016). Other contexts in which invitation to tender has impacted positively on performance includes the Nairobi city County Government (Gathima \& Njoroge, 2018); road construction sector (Chelimo, 2018); and in the United Nations Agencies situated in Nairobi (Waganda, 2018).

A review of existing literature nevertheless fails to exhaustively enumerate how invitation to tender can be utilized to prevent and minimize waste generation in the textile industry, and to pave way for waste management. It is on such a premise that hypothesis two presupposes that; H02: Invitation to tender has no significant influence on waste management in the textile industry in Kenya.

\subsection{Supplier Contract Structure and Waste Management}

Contracts have been defined as explicit and formal arrangements which set forth legally binding commitments and responsibilities which each party in the relationship is to undertake (Lyons \& Melita, 1997). Contracts are in essence viewed as structures that govern interactions between suppliers and buyers and which bar opportunistic tendencies within the transactions (Wacker, Yang \& Sheu, 2016). Chang, Gurbaxani and Ravindran (2017) on the one side and Huo et al. (2016) on the other, contend that detailed contracts specify mutual expectations, in which case opportunistic behaviour is limited.

Nevertheless, it has been argued that in certain occasions, contracts are incomplete leaving buyers and suppliers without relevant information required to specify safeguards and contingencies (Roenrich \& Lewis, 2014). Brown, Potoski and Van Slyke (2006) have on previous occasions demonstrated that such incompleteness in contract structure tends to offer an avenue for opportunistic suppliers to manipulate contracts to their own advantage. These observations raise the question of whether supplier contract structure has a role to play in the management of textile waste. The third hypothesis posits thus;

$\mathrm{H}_{0} 3$ : Supplier contract structure has no significant influence of waste management in the textile industry 
Figure 1 presents the conceptual framework of the postulations made.

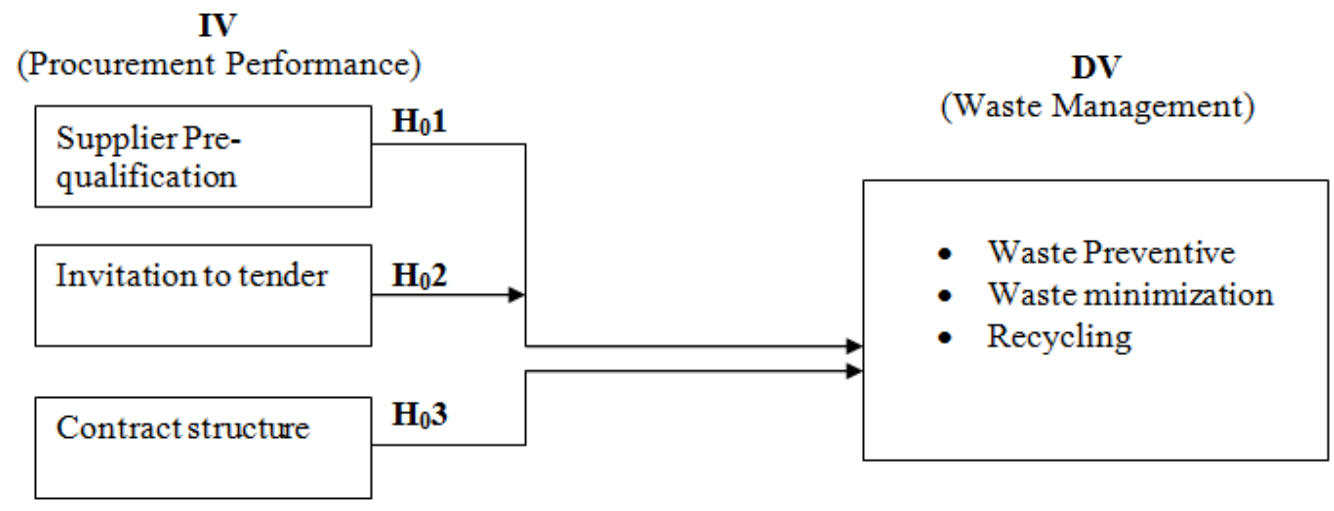

Figure 1 Conceptual framework

\section{Methodology}

\subsection{Study Design}

The focus of this study was on the influence of observed procurement performance constructs and those of waste management. The study was therefore grounded in the positivist research paradigm which advocates for quantitative approaches to research (Creswell, 2014). This study adopted the explanatory research design which has previously been successfully used in causeeffect studies (Saunders, Lewis \& Thornbill, 2009). In particular, the study employed the ex-post facto design which being quasi-experimental, did not require random assignment of subjects (Sharma, 2017).

\subsection{Target Population and Sampling Design}

The target population was employees working in the procurement department of textile firms located in Nairobi City County. On the basis of statistics sourced from the Kenya Textile Manufacturers Association (2016), fifteen textile firms were identified as being located in Nairobi City County. A reconnaissance study later revealed that the average number of employees in the firm's procurement department was 15 . The target population was therefore 225 employees. Cochran's 1975 sample size formula (as cited in Singh \& Masuku, 2014) was used to settle on a sample size of 142 employees. Data were collected using a structured questionnaire comprising of four sections consistent with the three procurement performance variables, and the waste management variable.

\subsection{Variable measurement}

The multi-item scales were self-developed and then refined following a series of pretests and reliability checks. Four scales namely; supplier pre-qualification, invitation to tender, contract structure and waste management were subsequently developed. The supplier pre-qualification scale comprised six items probing on ability of pre-qualification to prioritize prevention and minimization of waste generation. Invitation to tender was measured using five items reflecting bidder sensitivity to waste management. Contract structure was measured using five items focusing on the capability of the buyer-supplier contract to prioritize waste management. The waste management scale had eight items probing practices advanced towards waste management 
in the textile firms under investigation. Cronbach's alpha reliability measure was used to examine internal consistency among scale items.

\subsection{Data Analysis}

Data were analyzed using both descriptive and inferential statistics. Descriptive analysis focused on establishing whether procurement in textile firms in Nairobi City County was waste management sensitive, and the status of waste management in the firms under study. The principal approach to inferential analysis was multiple regressions. Under this approach, the waste management variable was entered as the dependent variable, while supplier prequalification, invitation to tender and contract structure were entered as the independent variables.

\section{RESUltS}

The pretest results confirmed that the self-developed scales were reliable as demonstrated by Cronbach's alpha values for supplier pre-qualification $(\alpha=0.723)$, invitation to tender $(\alpha=0.718)$, contract structure $(\alpha=0.803)$ and waste management $(\alpha=0.853)$. Regression residuals were uncorrelated as determined by a Durbin-Watson statistic value of 1.838. Meanwhile, there were no threats of multicollinearity with tolerance values of above $0.1(0.135-0.272)$, and variance inflation factors (VIF) below $10(3.678-7.414)$.

\subsection{Descriptive Analysis Results}

Descriptive analysis of whether pre-qualification practice in textile firms in Nairobi City County is conducted bearing waste generation in mind, indicated that it may not be the case (Table 1). The proportions of disagreements with the items were such that practices such as raising supplier awareness to waste prevention and minimization; seeking suppliers who prioritize waste prevention and minimization; targeting suppliers who are waste averse; and using prequalification to identify suppliers with an eye for waste forecasting were not being practiced.

Table 1 Pre-qualification practices employed in textile firms

\begin{tabular}{|c|c|c|c|}
\hline \multicolumn{4}{|c|}{ DisagreeundecidedAgree } \\
\hline $\begin{array}{l}\text { In this farm, prequalification is used to identify suppliers with ability to forecas } \\
\text { waste }\end{array}$ & $71.1 \%$ & $8.6 \%$ & $20.3 \%$ \\
\hline Prequalification gives the firm a strategic advantage of waste sensitive suppliers & $70.3 \%$ & $11.7 \%$ & $18.0 \%$ \\
\hline The firm targets suppliers with early site waste management plans (SWAP) & $66.4 \%$ & $14.8 \%$ & $18.8 \%$ \\
\hline $\begin{array}{l}\text { Through prequalification, the firm seeks suppliers whose priority is to preven } \\
\text { and minimize waste }\end{array}$ & $\mathrm{t}_{75.0 \%}$ & $10.2 \%$ & $14.8 \%$ \\
\hline The firm raises supplier awareness of waste prevention through prequalification & $77.3 \%$ & $12.5 \%$ & $10.2 \%$ \\
\hline The firm targets waste generation averse suppliers & $71.9 \%$ & $18.8 \%$ & $9.4 \%$ \\
\hline
\end{tabular}

Besides, practices employed when inviting tenders also seem to ignore the focus of waste management. On the basis of the large proportions of employees who tended to disagree (Table 2), it was apparent that it was not mandatory for suppliers who bid to prioritize waste prevention and minimization at all levels; suppliers also needed not to have ability to deliver objectives and targets for waste prevention; that bids did not need to prioritize waste reuse, recovery and recycle; and that a site waste management plan was not given emphasis. All this was happening despite suppliers being expected to aid in the prevention and minimization of waste generation in the textile supplier chain. 


\begin{tabular}{|c|c|c|}
\hline . . . . Disagree & $\underline{\text { undecided }}$ & $\underline{\text { Agree }}$ \\
\hline $\begin{array}{l}\text { This firm invites bids from suppliers with ability to deliver } 66.9 \% \\
\text { objectives and targets for waste prevention }\end{array}$ & $17.6 \%$ & $15.5 \%$ \\
\hline $\begin{array}{l}\text { Suppliers who bid are required to prioritize waste prevention and } \\
\text { minimization at all stages }\end{array}$ & $17.6 \%$ & $9.9 \%$ \\
\hline $\begin{array}{l}\text { The firm accepts bids only from suppliers who have the site } 63.4 \% \\
\text { waste management plan }\end{array}$ & $18.3 \%$ & $18.3 \%$ \\
\hline $\begin{array}{l}\text { Suppliers are expected to aid prevention and minimization of } 26.1 \% \\
\text { waste generation in the textile supply chain }\end{array}$ & $10.6 \%$ & $63.4 \%$ \\
\hline $\begin{array}{l}\text { Bids that guarantee waste reuse, recovery and recycle are given } 64.1 \% \\
\text { priority }\end{array}$ & $11.3 \%$ & $24.6 \%$ \\
\hline
\end{tabular}

In the case of supplier contract, it was clear that textile firms in question have failed to emphasize waste management in supplier contracts. Table 3 shows large proportions of disagreement with among others; the contract being clear on the role of SWMP in prioritizing actions and forecasting improvement; the contract being specific on firms commitment to waste management; the contract being clear on indicators of waste sensitive performance; the contract being explicit on materials needed to prevent or minimize waste; and supplier product performance being pegged on ability to prevent or minimize waste generation.

Table 3 Perceptions of contract structure employed in textile firms

\begin{tabular}{|c|c|c|c|}
\hline \multicolumn{4}{|c|}{ DisagreeundecidedAgree } \\
\hline $\begin{array}{l}\text { Re contract clearly specifies the firms commitment to waste prevention a } \\
\text { inimization }\end{array}$ & $62.0 \%$ & $16.2 \%$ & \\
\hline is explicit on materials needed to prevent or minimize waste & $59.2 \%$ & & \\
\hline & & & \\
\hline upplier product performance is pegged on ability to prevent or minimize waste & $57.0 \%$ & $13.4 \%$ & 29.6 \\
\hline $\begin{array}{l}\text { Te contract is clear on the role of site waste management plan in prioritizing } \\
\text { ctions and forecasting improvement }\end{array}$ & & $18.3 \%$ & $9.9 \%$ \\
\hline
\end{tabular}

The fourth variable explored was waste management as practiced in the textile firms. The results (Table 4) confirmed that proper waste management practices were not being closely adhered to in the firms. Employees for instance disagreed that; firm vehicles were being maintained in conditions to avoid air pollution; that environmental sensitivity is the criterion upon which suppliers were selected; that mechanisms were in place to enhance heat recovery from exhausted gases; that the firms do encourage collection and reuse of waste; and that firms recommend reusable packaging among others.

Table 4 Waste management practices employed in textile firms

The firm recommends reusable packaging environmental sensitivity is the criterion for supplier selection The firm collaborates with suppliers to improve environmental performance The firms vehicles are conditioned to avoid polluting the environment The firm procures materials on the basis of fossil and energy consumption The firm encourages collection and reuse of waste Mechanisms are in place to enhance heat recovery from exhausted gases Employees, customers and other stakeholders are involved in the firm's green initiatives
DisagreeundecidedAgree $62.7 \% \quad 5.6 \% \quad 31.7 \%$ $68.3 \% \quad 14.1 \% \quad 17.6 \%$

$60.6 \% \quad 10.6 \% \quad 28.9 \%$

$71.8 \% \quad 17.6 \% \quad 10.6 \%$

$57.7 \% \quad 21.1 \% \quad 21.1 \%$

$63.4 \% \quad 4.9 \% \quad 31.7 \%$

$66.9 \% \quad 14.8 \% \quad 18.3 \%$

$61.3 \% \quad 10.6 \% \quad 28.2 \%$ 
The multiple regression model summary (Table 5) confirmed that the three procurements performance measures explained up to $82.2 \%$ of the total variance in waste management (Rsquare $=0.822$ ).

Table 5 Model Summary ${ }^{\mathrm{b}}$

\begin{tabular}{llllll}
\hline Model & R & R Square & Adjusted R Square & Std. Error of the Estimate & Durbin-Watson \\
1 & $.906^{\mathrm{a}}$ & .822 & .817 & .23673 & 1.838 \\
\hline
\end{tabular}

a. Predictors: (Constant), contract structure, invitation to tender, supplier pre-qualification

b. Dependent Variable: waste management

Moreover, the ANOVA output (Table 6) indicated that the overall model relating procurement performance to waste management in the textile industry was statistically significant, $F(3,124)=$ $190.329, \mathrm{p}<0.001$.

Table 6 ANOVA $^{\text {a }}$

\begin{tabular}{lllllll}
\hline Model & & Sum of Squares & Df & Mean Square & F & Sig. \\
1 & Regression & 32.000 & 3 & 10.667 & 190.329 & $.000^{\mathrm{b}}$ \\
& Residual & 6.949 & 124 & .056 & & \\
& Total & 38.949 & 127 & & & \\
\hline
\end{tabular}

a. Dependent Variable: waste management

b. Predictors: (Constant), contract structure, invitation to tender, supplier pre-qualification

The regression coefficients output (table 7) confirmed that the predictors were significant with supplier pre-qualification, $\mathrm{b}=1.080, \mathrm{t}(124)=4.572, \mathrm{p}<0.001$ implying that for every 1 unit increase in waste sensitive pre-qualification, there was an equivalent of 1.08 units increase in waste management; for invitation to tender, $\mathrm{b}=0.429, \mathrm{t}(124)=3.336, \mathrm{p}<0.05$ implied that for every 1 unit increase in waste sensitive initiatives for inviting bids, an equivalent increase of 0.429 units was recorded in waste management; and for contract structure, $\mathrm{b}=0.419, \mathrm{t}(124)=$ $2.549, \mathrm{p}<0.05$ indicated that for every 1 unit increase in structure of contract, 0.419 units increase were registered in waste management. On the basis of the t-values, it was apparent that supplier pre-qualification contributed more to waste management, followed with invitation to tender and contract structure respectively.

Table 7Coefficients ${ }^{\mathrm{a}}$

\begin{tabular}{|c|c|c|c|c|c|c|}
\hline \multirow[b]{2}{*}{ Model } & \multicolumn{3}{|r|}{ Standardized } & & \multicolumn{2}{|c|}{ Collinearity Statistics } \\
\hline & B & Std. Error & Beta & $\mathrm{t}$ & Sig. Tolerance & VIF \\
\hline 1(Constant) & -1.042 & .140 & & -7.456 & .000 & \\
\hline supplier pre-qualific & n1.080 & .236 & .472 & 4.572 & .000 .135 & 7.414 \\
\hline invitation to tender & .429 & .129 & .243 & 3.336 & .001 .272 & 3.678 \\
\hline contract structure & .419 & .164 & .233 & 2.549 & .012 .172 & 5.804 \\
\hline
\end{tabular}

a. Dependent Variable: waste management

\section{DisCUSSIONS}

The study confirms that waste management in textile firms in Nairobi City County remains a challenge. The firms are still lax in bringing on board practices which prioritize waste management. Firms for instance, don't seem to be emphasizing enough on reusable packaging and collaborations with suppliers in the endeavour to prevent or minimize waste. Moreover, firms appear not to be involving suppliers, customers and other stakeholders in green initiatives. This is 
indeed regrettable considering that, stakeholder pressures have been associated with corporate environmental strategies (Wang, Li \& Qi, 2020). It is further argued that corporate social responsibility is an emerging concept that needs to be embraced in supply chains given the growing environmental concerns and regulatory impacts (Tekin, Erturk \& Tozan, 2015).

The finding showing non-involvement of stakeholders in green initiatives and minimal collaborations with suppliers in matters concerning environmental performance is indeed a worrying picture basing on the understanding that stakeholders have a positive influence on a firm's environmental strategy (Lindblom \& Ohlsson, 2011). Meanwhile, the finding that textile firms in Nairobi City County were not putting emphasis on reusable packaging defeats NEMA's desire for 'Zero Waste' in the country by 2030 (NEMA, 2015).

The study also established that procurement in the firms, conducted through functions such as supplier pre-qualification, invitation to tender, and contract structure fails to factor the element of waste generation and management. Supplier pre-qualification for instance does not prioritize ability to forecast waste, and early site waste management plans among other waste prevention strategies. Invitations to tender and contract structure are also done without giving prominence to waste management. Such findings perhaps explain why the status of waste management in the firms appears to be poor. Supplier pre-qualification features in risk management discourse as a critical element which is used to identify suppliers who share in the values and performance expectations of the firm (Gold Fields, 2020). By failing to invest in supplier pre-qualification which is waste management sensitive, firms may therefore not be able to guarantee selection of suppliers who can help prevent waste generation.

The multiple regressions indicated that supplier pre-qualification, invitation to tender, and contract structure were positive and significant predictors of waste management in the textile firms under investigation. This confirmed that lack of emphasis on waste management during procurement could be attributed to the poor waste management practices experienced in the firms. As a matter of fact, procurement functions such as supplier pre-qualification (Limo et al., 2017; Naibor \& Moronge, 2018; Pikonsova \& Prusa, 2013); invitation to tender (Chelimo, 2018; Waganda, 2018); and contract structure (Wacker et al., 2016) have previously been found to have positive impacts on organizational performance. The argument posited here therefore is that such functions can be leveraged upon to improve waste management in textile firms in Nairobi City County.

\subsection{Theoretical and Managerial Implications}

The findings reported in this study have important ramifications for theory and practice of procurement performance and waste management. From a theoretical perspective, the findings strengthen the importance of the procurement functions of pre-qualification, invitation to tender, and contract structure in the purchasing process. Perhaps, the main contribution is that such functions can be employed to prevent and minimize waste generation in firms. Although the procurement process has been found essential in waste minimization in the construction industry (Waste \& Resources Action Programme, n.d.), the findings in this study extends the importance of procurement to waste management from a textile industry supply chain perspective. Besides, the study delineates the actual procurement process components that ought to be engaged.

Managerial-wise, the study underscores the central role that procurement stands to play in waste management in the textile industry. This no doubt informs the requisite action that textile industry stakeholders and policy makers ought to take if indeed Kenya is to attain 'zero waste' as stipulated in Nema's solid waste management strategy (NEMA, 2015). Textile firm management 
ought to instill a culture that is waste management sensitive by infusing the waste management elements in the procurement functions of pre-qualification, tender bidding, and contract structure. In this way, the firms can be able to prevent or minimize waste and contribute towards realization of the 'zero waste' initiative.

\subsection{Conclusions}

Textile firms in Nairobi City County are lagging behind in the endeavour to manage waste. Most of the firms are not putting great emphasis on waste management practices. However, all this can be altered through procurement processes. By turning towards procurement functions such as prequalification, invitation to tender and contract structure, the firms can be in positions to engage suppliers who share in their waste management ethos. The three functions have a positive impact on waste management and are therefore critical to achievement of 'zero waste' in the industry. By designing these three functions with waste management in mind, textile firms in Nairobi City County have the potential to minimize and prevent waste generation.

\subsection{Limitations}

By relying on textile firms drawn only from Nairobi City County, the true picture of waste management in the textile industry may not have been captured. Moreover, the procurement process is an elaborate process that encompasses other crucial functions which were not captured in this study. The study findings were further limited in the sense that the study relied only on employees views as opposed to views of suppliers and other stakeholders.

\subsection{Recommendations for Future Studies}

Future studies should improve the target population to include other counties for purposes of generating findings that can have wide generalizability. Future studies also need to bring on board the views of other stakeholders and particularly those of suppliers. Although use of the three procurement functions in this study explained a high percentage of the variance in waste management, efforts should in future focus on identifying other critical procurement functions that can help explain the remaining $17.8 \%$ of the variance in waste management.

\section{ACKNOWLEDGEMENT}

The author could like to thank the Government of Kenya through the National Commission for science technology and innovation for promoting knowledge, increased awareness and adequate information of research system. Special thanks to all the respondents who contributed to the success of the study.

\section{REFERENCES}

[1] Gakungu, N. K., Gitau, A. N., Njoroge, B.N. K. \& Kimani, M.W. (2012). Solid Waste Management in Kenya: A case study of public technical training institutions. ICASTOR Journal of Engineering 5(3): 127-138.

[2] National Environment Management Authority (2014). THE NATIONAL SOLID WASTE MANAGEMENT $\quad$ STRATEGY. https://www.nema.go.ke/images/Docs/Media\%20centre/Publication/National\%20Solid\%20Waste\%2 0Management $\% 20$ Strategy\%20.pdf

[3] Kinyanjui, J., Mburu, A.W. \& Waithaka, A. (2013). CONVERSION OF TEXTILE AND LEATHER WASTES INTO NONWOVEN PRODUCTS. 2ND NATIONAL SCIENCE, TECHNOLOGY AND INNOVATION WEEK 
[4] Sundqvist, J-O., Palm, D. (2010), Miljöpåverkan från avfall - Underlag för avfallsprevention och förbättrad avfallshantering. Report B1930. IVL Swedish Environmental Research Institute Ltd

[5] UNDP Practice Series, Environmental Procurement, September 2008. Environmental Procurement. https://www.greeningtheblue.org/sites/default/files/UNDP-Environmental\%20procurement_0.pdf

[6] Sustainability exchange (2020). Purchasing and procurement. Retrieved on 12/3/2020 from https://www.sustainabilityexchange.ac.uk/purchasing_and_procurement

[7] Michael-Agwuoke, M. U. (2012). Is waste-to-energy changing the definition of waste? presented at the 3rd International chemical and environment conference ICEEC 2012, Kuala Lumpur, Malaysia, 21-23 December, 2012

[8] Amasuomo, E. \& Baird, J. (2016). The Concept of Waste and Waste Management. Journal of Management and Sustainability, 6(4)

[9] Ashfaq, A. \& Khatoon, A. (2014). Waste Management of Textiles: A Solution to The Environmental Pollution. International Journal of Current Microbiology and Applied Science, 3(7): 780-787

[10] Sachidhanandham, A. (2018). Waste Management Technologies in Textile Industry. Innovative Energy \& Research. 07. 10.4172/2576-1463.1000211.

[11] Fletcher, K. (2008). Sustainable Fashion and Textiles, Design Journeys, Earthscan, London.

[12] DEFRA (2009). Maximising Reuse and Recycling of UK Clothing and Textiles. http://www.oakdenehollins.co.uk/pdf/defra_173_summary_issue_4.pdf

[13] Fraser, Kim. 2009. ReDress: refashion as a solution for clothing (un)sustainability. Master's Thesis, AUT University, Auckland

[14] Chao, L. C., \& Hsiao, C. S. (2012). Fuzzy model for predicting project performance based on procurement experiences. Automation in Construction, 28, 71-81.

[15] Ntayi, J. M. (2013). Leadership Styles, Workplace Politics and Moral Identity of Ugandan Public Procurement Staff. International Journal of Public Administration, 36(1), 35-44.

[16] Naibor, G. S.\& Moronge, M. (2018). Influence of Supplier Selection Criteria on Performance of Manufacturing Companies in Kenya. The Strategic Journal of Business \& Change Management, 5(1): $355-377$

[17] Limo, G.C., Iravo, M.A. \& Lagat, M.K. (2017). Effects of Pre- Qualification of Suppliers on Procurement Performance of the Judiciary in Kenya. International Journal of Recent Research in Commerce Economics and Management (IJRRCEM), 4(3): 57-70

[18] Tasmania. (2006).Department of treasury and finance. Guidelines on tender evaluation using weighted criteria for works and services.

[19] SUED (2019). Invitation to Tender (ITT) Investment Attraction Firm. Retrieved on 12/11/20 from https://nairobichamber.co.ke/wpcontent/uploads/2019/08/576a4e_86f0b32267bc41eb82e34647678ae185.pdf

[20] Lyons, B. \& Mehta, J. (1997), Contracts, opportunism and trust: self-interest and social orientation, Cambridge Journal of Economics, 21 (2): 239-257.

[21] World Bank. (2008). Public Sector Reform: What works and what doesn't?An Independent Evaluation Group Evaluation of the World Bank. Washington DC. World Bank

[22] Flynn, A. \& Davis, P. (2016). Investigating the effect of tendering capabilities on SME activity and performance in public contract competitions. International Small Business Journal. 35. $10.1177 / 0266242616630035$.

[23] Gathima,J.I. \& Njoroge, J.G. (2018). Effects of E-Tendering on Organization Performance in Public Sector: A Case of Nairobi City County Government. Strategic Journal of Business \& Change Management, 5(3).

[24] Wacker, J.G., Yang, C. \& Sheu, C. (2016), A transaction cost economics model for estimating performance effectiveness of relational and contractual governance:

[25] Roehrich, J. \& Lewis, M. (2014), Procuring complex performance: implications for exchange governance complexity, International Journal of Operations \& Production Management, Vol. 34 (2): 221-241.

[26] Brown, T.L., Potoski, M. \& Van Slyke, D.M. (2006), Managing public service contracts: aligning values, institutions, and markets, Public Administration Review, Vol. 66(3): 323-331.

[27] Creswell, J. W. (2014). Research Design Qualitative, Quantitative, and Mixed Methods Approaches (4th ed., p. 304). Thousand Oaks, CA: SAGE Publications.

[28] Saunders, M \& Lewis, P. \& Thornbill, A.. (2009). Research Methods for Business Studies. 
[29] Wang, L., Li, W. \& Qi, L. (2020). Stakeholder Pressures and Corporate Environmental Strategies: A Meta-Analysis. Sustainability 2020, 12, 1172; doi:10.3390/su12031172

[30] Tekin, E.K., Ertürk, A. \& Tozan, H. (2015). Corporate Social Responsibility in Supply Chains, Applications of Contemporary Management Approaches in Supply Chains, DOI: 10.5772/59582. Available from: https://www.intechopen.com/books/applications-of-contemporary-managementapproaches-in-supply-chains/corporate-social-responsibility-in-supply-chains

[31] Lindblom, A. \& Ohlsson, J. (2011). Stakeholders' Influence on the Environmental Strategy of the Firm. A Study of the Swedish Energy Intensive Industry. Dissertation in TPA, 15 ECTS submitted to Halmstad University.

[32] Gold Fields (2020). Supplier pre-qualification. Retrieved on 12/10/2020 from https://www.goldfields.com/supplier-pre-qualification.php

[33] Chelimo, F.C. (2018). Effects of Tendering Process on Services Delivery in Road Construction Sector. A Case of Kerra. Master's Thesis Submitted to Jomo Kenyatta University of Agriculture and Technology

[34] Waganda, A.O. (2018). Effect of Electronic Procurement on Performance of United Nations Agencies in Nairobi: A Study of Selected UN Agencies in Nairobi. Master's Thesis Submitted to United States International University - Africa

\section{AUTHOR}

Dr.Enock Gideon Musau with over 6 years of experience as a Lecturer and Programme Leader for purchasing and supplies management based at the department of management science in the School of business and economics Kisii University Kenya. He has Ph.D. in Supply Chain Management from Jomo Kenyatta University of Agriculture and Technology, Nairobi, Kenya, Master of Science (MSc) in Procurement and logistics from Jomo Kenyatta University of Agriculture and Technology, Nairobi, Kenya and Bachelor of Business ManagementPurchasing and supplies, Moi University, Eldoret, Kenya. He has extensive administrative and management experience in the private sector particularly in the transport and logistics sector. His research interests include but not limited to

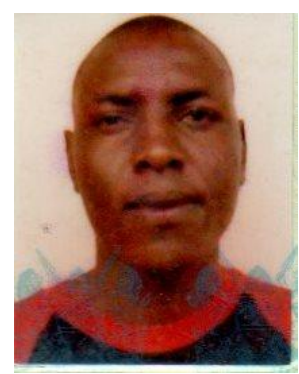
Supply chain Management, Value chain Management, Supply Chain Information technology in service delivery and distribution, Logistics management and planning, Demand forecasting and planning and change Management. 